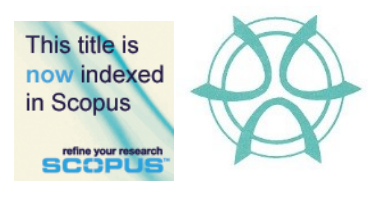

PLANNING MALAYSIA:

Journal of the Malaysian Institute of Planners

VOLUME 19 ISSUE 3 (2021), Page 180 - 189

\title{
VALUATION OF MARKET RENTAL VALUE OF A PLANNED DORMITORY USING HEDONIC PRICING METHOD: A CASE STUDY OF POLYTECHNIQUE OF STATE FINANCE STAN, INDONESIA
}

\author{
Doni Triono ${ }^{1}$, Akhmad Solikin ${ }^{2}$ \\ ${ }^{1}$ Department of Financial Management \\ POLYTECHNIQUE OF STATE FINANCE STAN, INDONESIA \\ ${ }^{2}$ Department of Accounting \\ POLYTECHNIQUE OF STATE FINANCE STAN, INDONESIA
}

\begin{abstract}
This study determines the attributes that affect the market rental value of dormitories using the Hedonic Pricing Model. The proportional stratified random sampling technique was used to obtain data from 1,292 PKN STAN students in levels 1 to 3, which was analyzed using the SPSS statistical application. Based on the calculation, the dormitory value varies between IDR11,719,521 (RM3,424.82) to IDR15,482,242 (RM4524,41). The determinants that have a significant positive effect on dormitory value are bathroom location, average remittances per month, earnings per month, room size, gender, and origin, while the type of residence attribute has a negative correlation effect. The results of this study will be beneficial inputs for the PKN STAN in determining the market rental value, the quality of buildings and facilities are in accordance with the market preference.
\end{abstract}

Keywords: Market Rental Valuation, Hedonic Pricing Model, Willingness to Pay

\footnotetext{
${ }^{1}$ Lecturrer at Polytechnique of State Finance STAN, Indonesia. Email : dony_triono@pknstan.ac.id
} 


\section{INTRODUCTION}

Polytechnic of State Finance STAN (PKN STAN) is a state campus under the Ministry of Finance, Indonesia. Graduates of this higher institution are directly recruited as government officials for the Ministry of Finance and state institutions in Indonesia. PKN STAN is among the favourite campuses in Indonesia, attracting more than 100,000 applicants every year with approximately 2,000 freshmen. The campus offers free tuition, while students bear accommodations and meals.

However, this polytechnic plan to build dormitories to improve discipline, safety, esprit de corps, and monitor students' activities in and around its surroundings. The planned dormitories are intended for students, and the occupants are required to pay rent. According to analysts, the planned dormitory would likely decrease the prices of rental houses or rooms in areas near the PKN STAN campus. The additional rooms supply will undoubtedly lead to an increase in empty rooms, thereby mandating the owners to reduce rental prices to attract new tenants. Therefore, this research also aims to analyze the new equilibrium of rental price.

This policy is likely to affect land asset utilization for PKN STAN to become more productive. It creates an avenue for the polytechnic to generate revenue as a public service agency (Badan Layanan Umum) which legally has the right to levy fees on its services. Students varying financial abilities need to be taken into account when setting the rental price. This study also aims to estimate rental prices based on students' preferences by revealing their preference for available facilities and services provided. Furthermore, this study applied the hedonic price model (HPM), which has been widely implemented to appraise the effect of respondents' willingness to pay in accordance with residential property value.

\section{LITERATURE REVIEW}

According to Palmquist (1984) utility of a property is determined by its physical and external attributes. The HPM is suitable for this study due to its effect on the characteristics on the value of a property. The valuation approach is applied to dormitory property planned in the PKN STAN from 2020 to 2022.

HPM is a valuation model used to estimate someone's preferences in paying for the value of goods and services through its attributes. According to Orford (2000), this strategy has been used extensively in the property industry to evaluate peoples' preferences. Hanley, Shogren, \& White (1997) defined it as an economic valuation model based on respondents' preferences to pay for goods or services in accordance with the attributes of the property.

Furthermore, Ready, Berger, and Blomquist (1997) stated that HPM can be implemented to calculate the value of agricultural land. Preliminary studies implement it to evaluate the monetary impact of environmental damage, such as air pollution, sedimentation, and landfills (Hite et al., 2001). In addition, Brendt (1990) used HPM to estimate prices in the car and computer industries. 
Doni Triono \& Akmad Solikin

Valuation Of Market Rental Value of a Planned Dormitory Using Hedonic Pricing Method: A Case Study of

Polytechnique of State Finance STAN, Indonesia

Therefore, information regarding the willingness to pay in accordance with HPM analysis is beneficial to stakeholders in the government and private sectors. This evaluation model also provides valuable information on the value of specific goods and services and informs policymakers.

The hedonic price model is one of the methods suitable for valuing and replacing special goods that do not have market values. HPM is commonly used in valuing property (Bolt et al., 2005). It assumes that physical property is an attribute that reflects community preferences for property and is used as a reference in determining its value.

The physical attributes of the hostel include location, room area, elevator, study table, bed, wardrobe, and wifi. This is in addition to the property externalities such as distance from campus. The frequent use of statistical analysis and multiple regression models makes it possible to isolate the effects of the features considered to be assessed.

\section{METHODOLOGY}

Theoretically, property value is determined by its attributes which people then consume to fulfill its demand. Therefore, studies need to be carried out to construct regression functions with dependent variables, such as dormitory rental price and the independent variables. According to Cró and Martins (2017), several attributes affect dormitory prices, such as staff, facilities, atmosphere, cleanliness, location, and security. However, Santos (2016), Tsai, and Pan (2014) state that attributes such as location, daylighting, facilities, service quality, and security are the dominant factors affecting dormitory prices.

The rental price of an apartment is determined by its physical and environmental attributes (Anselin, 1988; Dubin, 1992). The mathematical expression is shown in equation (1).

$R=f(P, E)$

where R, P, and E denotes dormitory rent, physical conditions, and environmental attributes.

Kong, Yin, and Nakagoshi (2007) and Bolt et al. (2005) reported that choosing attributes that affect property value is imperative because they are used in the multiple regression as independent variables. In addition to physical facilities and environmental attributes, this research also included some socioeconomic variables to capture the effect of socioeconomic status on willingness to pay (Mohit \& Mustafa, 2010). Therefore, the attributes and socioeconomic variables include:

1. Physical attributes, such as type of current room (house, room, or apartment), room size, location of shower/toilet (inside or shared), electricity bill, kitchen, and parlor.

2. External attributes, such as distance or time-traveled to the campus, transportation type, and food provider. We do not include open space 
(Asmawi et al., 2018) as an external attributes since we assume that the open space is not relevant for majority of students.

3. Socioeconomic attributes, such as income (from family or own revenue), department, semester, age, place of origin, gender, family member, and parents' professions.

The empirical model of multiple linear regressions is shown in equation (2):

$$
\begin{aligned}
& Y_{i}=\beta+\beta_{1} \text { TYPE }_{i}+\beta_{2} \text { ELEC }_{i}+\beta_{3} \text { SHARED }_{i}+\beta_{4} \text { KITCHEN }_{i}+\beta_{5} \mathrm{SIZE}_{i} \\
& +\beta_{6} \mathrm{BATH}_{i}+\beta_{7} \mathrm{REMIT}_{i}+\beta_{8} \mathrm{INCOME}_{i}+\beta_{9} \mathrm{DEPT}_{i}+\beta_{10} \mathrm{SEM}_{i}+ \\
& \beta_{11} \mathrm{AGE}_{i}+\beta_{12} \mathrm{ORI}_{i}+\beta_{13} \mathrm{GENDER}_{i}+\beta_{14} \mathrm{FAM}_{i}+\beta_{15} \mathrm{JOB}_{i}+ \\
& \beta_{16} \mathrm{DIST}_{i}+\varepsilon_{i}
\end{aligned}
$$

where $Y i=$ Dormitory value, $\beta=$ intercept, $\beta_{1 . . n}=$ coeficient correlation, TYPE $=$ type of place, ELEC $=$ electricity cost, SHARED $=$ shared space, KITCHEN = shared kitchen, SIZE $=$ room size, BATH $=$ the location of the bathroom, REMIT $=$ Average remittances per month, INCOME $=$ own income, $\mathrm{DEPT}=$ Departmen, $\mathrm{SEM}=$ semester, $\mathrm{AGE}=$ age, $\mathrm{ORI}=$ origin, $\mathrm{GENDER}=$ gender, $\mathrm{FAM}=$ family number, $\mathrm{JOB}=$ profession parents, $\mathrm{DIST}=$ distance to campus.

The sample in this study was Campus PKN STAN students of all department levels, namely Accounting, Tax, Customs and Excise, and Financial Management. The sampling technique used was stratified random sampling by randomly select sample based on attendance numbers list. The data will be analyzed using the ordinary least square (OLS) method by a stepwise selection of variables. This method is the same as the research conducted by Majid et al. (2018).

\section{FINDING AND DISCUSSION}

\section{Descriptive Statistics}

The sample population consists of 10,756 students grouped into 287 per class at all levels. Out of the 1289 respondents, $1236(95.9 \%)$ agreed and strongly agreed with the construction of dormitories in the campus area. Meanwhile, $912(70.7 \%)$ were aware of the planned construction of the dormitories. 1,064 (82.5\%) lived with a distance of 0-500 meters and $167(12.9 \%)$ at 501-1500 meters. The remaining $58(4.5 \%)$ lived at a distance of $1.5-11 \mathrm{~km}$. Therefore, it can be concluded that the current significant number of students mostly live around the campus. It is logical that our models do not include transportation choice, albeit previous literatures found it significant predictors of rents (Suhaimi et al., 2021).

Table 1: Composition of Respondents Based on Gender, Level and Department

\begin{tabular}{cccccccccc}
\hline \multirow{2}{*}{ No } & \multirow{2}{*}{ Department } & \multicolumn{4}{c}{ Male } & Female \\
\cline { 3 - 11 } & & I* & III & V & VII & I & III & V & VII \\
\hline 1. & Accounting & 151 & 127 & 76 & 0 & 90 & 186 & 70 & 0 \\
\hline
\end{tabular}


Doni Triono \& Akmad Solikin

Valuation Of Market Rental Value of a Planned Dormitory Using Hedonic Pricing Method: A Case Study of Polytechnique of State Finance STAN, Indonesia

\begin{tabular}{|c|c|c|c|c|c|c|c|c|c|}
\hline 2. & Tax & 80 & 53 & 29 & 0 & 28 & 79 & 21 & 0 \\
\hline 3. & $\begin{array}{l}\text { Customs and } \\
\text { Excises }\end{array}$ & 1 & 13 & 28 & 0 & 0 & 0 & 3 & 0 \\
\hline 4. & $\begin{array}{l}\text { Financial } \\
\text { management }\end{array}$ & 52 & 45 & 10 & 0 & 41 & 82 & 24 & 0 \\
\hline \multicolumn{2}{|c|}{ Total } & 284 & 238 & 143 & 0 & 159 & 347 & 118 & 0 \\
\hline \multicolumn{2}{|c|}{ Grand total } & 1289 & & & & & & & \\
\hline
\end{tabular}

* Level/semester

The composition of respondents by gender, level, and department is shown in Table 1 . Based on gender, the number of respondents consists of 665 $(51.6 \%)$ male and $624(48.4 \%)$ female students. In terms of origin, $893(69.3 \%)$ of the respondents come from Java, Bali, and Nusa Tenggara, while $335(26 \%)$, $29(2.3 \%), 29(2.3 \%)$, and $3(0.2 \%)$ are from Sumatra, Kalimantan, Sulawesi, and Papua, respectively. Furthermore, there are 700 (54.3\%), 290 (22.4\%), 45 (3.5\%), and 254 (19.7\%) Department of Accounting, Department of Tax, Department of Customs and Excise, and Department of Financial Management.

\section{Regression Analysis}

Parameter Estimation

Parameter estimation in this regression uses the ordinary least square (OLS) method by a stepwise selection of variables. It is a combination of forward and backward methods, with the first variable consisting of the highest and significant correlation with the dependent variable. The second incoming variable with the highest value is still a significant and partial correlation. Furthermore, after certain variables enter the model, others are evaluated to eliminate those that are not significant (Draper \& Smith, 1998).

From 7 possible models, the $7^{\text {th }}$ model can explain the effect of variables used up to 7 variables. Therefore, model 7 will be used. As shown in Table 1, bathroom location, average monthly remittances, own earnings per month, room size, type of residence (others), gender (male), and place of origin (Kalimantan island), are all significant at $5 \%$.

Table 2: Coefficients

\begin{tabular}{|c|l|r|r|r|r|r|r|}
\hline \multicolumn{2}{|c|}{ Model } & \multicolumn{1}{|c|}{ B } & Std. Err. & \multicolumn{1}{c|}{ t } & Sig. & Tol & VIF \\
\hline 1 & (Constant) & 9909483 & 307905 & 32.184 & .000 & & \\
& Bathroom location & 3460185 & 446147 & 7.756 & .000 & 1.000 & 1.000 \\
\hline 2 & (Constant) & 8189247 & 484983 & 16.886 & .000 & & \\
& Bathroom location & 3240819 & 439284 & 7.378 & .000 & .988 & 1.012 \\
& Average remittances (month) & 1.402 & .310 & 4.527 & .000 & .988 & 1.012 \\
\hline \multirow{2}{*}{3} & (Constant) & 6768582 & 593756 & 11.400 & .000 & & \\
& Bathroom location & 3316224 & 432331 & 7.671 & .000 & .986 & 1.014 \\
& Average remittances (month) & 1.933 & .332 & 5.823 & .000 & .831 & 1.203 \\
\hline
\end{tabular}


PLANNING MALAYSIA

Journal of the Malaysia Institute of Planners (2021)

\begin{tabular}{|l|l|r|r|r|r|r|r|}
\hline & Earnings per month & .931 & .232 & 4.016 & .000 & .835 & 1.197 \\
\hline 4 & (Constant) & 5054363 & 801417 & 6.307 & .000 & & \\
Bathroom location & 2961641 & 442595 & 6.692 & .000 & .922 & 1.085 \\
& Average remittances (month) & 1.805 & .331 & 5.453 & .000 & .819 & 1.222 \\
Earnings per month & .815 & .233 & 3.503 & .001 & .814 & 1.228 \\
& Room size & 220628 & 70109 & 3.147 & .002 & .909 & 1.100 \\
\hline 5 & (Constant) & 4910736 & 797510 & 6.158 & .000 & & \\
& Bathroom location & 2816514 & 442735 & 6.362 & .000 & .908 & 1.101 \\
& Average remittances (month) & 1.822 & .329 & 5.541 & .000 & .818 & 1.222 \\
Earnings per month & .827 & .231 & 3.579 & .000 & .814 & 1.229 \\
Room size & 245199 & 70205 & 3.493 & .001 & .893 & 1.119 \\
& Type of residence (others) & -6094337 & 2258613 & -2.698 & .007 & .973 & 1.028 \\
\hline 6 (Constant) & 4293484 & 818644 & 5.245 & .000 & & \\
Bathroom location & 2561503 & 447627 & 5.722 & .000 & .874 & 1.145 \\
Average remittances (month) & 1.852 & .326 & 5.678 & .000 & .817 & 1.223 \\
& Earnings per month & .860 & .229 & 3.749 & .000 & .812 & 1.232 \\
Room size & 259623 & 69787 & 3.720 & .000 & .889 & 1.125 \\
Type of residence (others) & -6692091 & 2248877 & -2.976 & .003 & .965 & 1.036 \\
Gender (Male) & 1260031 & 432426 & 2.914 & .004 & .953 & 1.049 \\
\hline 7 (Constant) & 4254244 & 814508 & 5.223 & .000 & & \\
Bathroom location & 2487704 & 446361 & 5.573 & .000 & .869 & 1.150 \\
Average remittances (month) & 1.800 & .325 & 5.534 & .000 & .814 & 1.229 \\
Earnings per month & .833 & .228 & 3.646 & .000 & .810 & 1.235 \\
Room size & 267198 & 69493 & 3.845 & .000 & .887 & 1.127 \\
Type of residence (others) & -6662045 & 2237091 & -2.978 & .003 & .965 & 1.036 \\
Gender (Male) & 1275017 & 430199 & 2.964 & .003 & .953 & 1.049 \\
Origin (Kalimantan) & 3052249 & 1287452 & 2.371 & .018 & .989 & 1.011 \\
\hline
\end{tabular}

\section{Model Evaluation}

Model evaluation consists of testing 4 (four) assumptions namely normality, nonmulticollinearity, non-heteroscedasticity, non-autocorrelation. As shown in Table 3 , all regression assumptions are met.

Table 3: Gaus-Markov Assumption

\begin{tabular}{|c|c|c|c|c|}
\hline No. & Assumptions & $\begin{array}{c}\text { Technical } \\
\text { testing }\end{array}$ & Test Tools & Conclusion \\
\hline 1 & Normality & PP-Plot & $\begin{array}{l}\text { PP plots meet diagonal } \\
\text { normality line }\end{array}$ & Fulfilled \\
\hline 2 & $\begin{array}{l}\text { Non- } \\
\text { Multicollinearity }\end{array}$ & VIF & VIF value is lower than 10 & Fulfilled \\
\hline 3 & $\begin{array}{l}\text { Non- } \\
\text { Heteroscedasticity }\end{array}$ & $\begin{array}{l}\text { scatter/plot } \\
\text { diagram } \\
\text { between }\end{array}$ & $\begin{array}{l}\text { the distribution of plots } \\
\text { shows a random pattern }\end{array}$ & Fulfilled \\
\hline
\end{tabular}


Doni Triono \& Akmad Solikin

Valuation Of Market Rental Value of a Planned Dormitory Using Hedonic Pricing Method: A Case Study of Polytechnique of State Finance STAN, Indonesia

\begin{tabular}{|c|l|l|l|l|}
\hline & $\begin{array}{l}\text { residuals }(e i) \\
\text { and estimated } \\
\text { values }(Y \hat{i})\end{array}$ & & \\
\hline 4 & Non-Autocorrelation & $\begin{array}{l}\text { Durbin- } \\
\text { Watson }\end{array}$ & $\begin{array}{l}\text { DW value of 2,074 is } \\
\text { close to 2 }\end{array}$ & Fulfilled \\
\hline
\end{tabular}

Interpretation Model

a. Simultaneous Significance Test ( $F$ Test)

Table 4: Anova ${ }^{\mathrm{a}}$

\begin{tabular}{llllllr}
\hline \multicolumn{1}{c}{ Model } & \multicolumn{1}{c}{ Sum of Squares } & \multicolumn{1}{c}{ df } & \multicolumn{1}{c}{ Mean Square } & \multicolumn{1}{c}{ F } & Sig. \\
\hline 7 & Regression & 2695794528394240 & 7 & 385113504056320 & 20.118 & $.000^{\mathrm{h}}$ \\
Residual & 8326987638648644 & 435 & 19142500318733 & & \\
Total & 11022782167042884 & 442 & & &
\end{tabular}

$\mathrm{H}_{0}$ : The independent variable does not have a simultaneous influence on the dependent variable.

$\mathrm{H}_{1}$ : The independent variable influences the dependent variable simultaneously.

$F$ Test - reject $\mathrm{H}_{0}$ because prob $<5 \%$, it can be concluded that the independent variable has a simultaneous influence on the dependent variable.

b. Partial significance test (t-Test)

A partial test is used to determine the independent variable that influences the dependent. This test result is shown in the table above.

$\mathrm{H}_{0}$ : the independent variable does not influence the dependent variable

$\mathrm{H}_{1}$ : the independent variable influences the dependent variable

The results are determined from the prob of each variable in the model above.

c. The Goodness of Fit $\left(\mathrm{R}^{2}\right)$

Based on the adjustment $\mathrm{R}^{2}$ value of 0.232 from Model 7 in the Summary table during the autotest, it is concluded that the independent variable in the model is used to explain $23.2 \%$ of the variation of the dependent variable. Meanwhile, the remaining is explained by other variables not included in the model.

\section{Analysis Result}

The regression results of the dormitory value are as follows:

Dormitory value $=4,254,243+2,487,704$ (Bathroom location) +1.800 (Average Remittances per Month) +0.833 (Earnings per Month) + 267,197 (Room Size) - 6,662,045 (Type of Residence, others) + 1,275,016 (Gender, Male) + 3,052,248 (Origin, Kalimantan)

The bathroom location has a positive effect on the dormitory value, assuming it is located inside the room. The difference in value is IDR2,487,704 larger than when it is located outside the room. This is because when the bathroom is located inside the room, it increases the comfort and privacy of its residents. Average remittance per month also has a positive effect on the dormitory value. For 
instance, an increase in the monthly transfer by IDR1,000,000 tend to affect the dormitory value to IDR1,800,000. This is because people with a higher average remittance per month have a more significant ability to pay dormitory rent, which increases the value. The earnings per month factor also have a positive effect on the dormitory value.

For instance, an increase in its monthly value by IDR1,000,000 leads to a rise in the dormitory value to IDR833,000. This is because those from families with higher income are more willing to pay rent with greater value. The model also indicates that room size affects the dormitory value, with an increase of IDR267,197 for every $1 \mathrm{~m}^{2}$. This is because the wider the room, the more functionality its uses. When the type of residence is in the form of owned or rented house, it does affect the dormitory value. However, supposing it is in other types, it reduces the dormitory value by IDR6,662,045. Gender also has a positive effect on it, with male affecting its value by IDR 1,275,016 compared to females. The origin of students from Kalimantan also positively affects the dormitory value by IDR3,052,248 as opposed to those from Sumatra, Java and Bali, Sulawesi, and Papua. Table 5 shows the dormitory value from variations 1 to 4 .

Table 5: Dormitory Value

\begin{tabular}{|c|c|c|c|c|}
\hline Attribute type & Variation 1 & Variation 2 & Variation 3 & Variation 4 \\
\hline $\begin{array}{l}\text { Bathroom } \\
\text { location }\end{array}$ & in the room & in the room & $\begin{array}{l}\text { outside the } \\
\text { room }\end{array}$ & $\begin{array}{l}\text { outside the } \\
\text { room }\end{array}$ \\
\hline $\begin{array}{l}\text { Average } \\
\text { remittances per } \\
\text { month }\end{array}$ & IDR $1,000,000$ & IDR1,000,000 & IDR1,000,000 & IDR1,000,000 \\
\hline $\begin{array}{l}\text { Earnings } \\
\text { month }\end{array}$ & IDR250,000 & IDR250,000 & IDR250,000 & IDR250,000 \\
\hline Room size & $9 \mathrm{~m}^{2}$ & $9 \mathrm{~m}^{2}$ & $9 \mathrm{~m}^{2}$ & $9 \mathrm{~m}^{2}$ \\
\hline $\begin{array}{l}\text { Type } \\
\text { residence }\end{array}$ & Rent a house & Rent a house & Rent a room & Rent a room \\
\hline Gender & Male & Female & Male & Female \\
\hline Origin & Java & Java & Java & Java \\
\hline Dormitory value & IDR15,482,242 & IDR14,207,225 & IDR12,994,538 & IDR11,719,521 \\
\hline
\end{tabular}

\section{CONCLUSION}

In conclusion, the variables that have a significant positive effect on dormitory value are bathroom location, average remittances per month, earnings per month, room size, gender, and origin, while the type of residence attribute has a negative correlation effect. Based on the simulation results, the highest simulation value is IDR15,482,242 (RM4524,41), with the bathroom located in the room, average remittances per month of IDR1,000,000, earnings per month of IDR250,000, room size of $9 \mathrm{~m}^{2}$, type of residence of rent a house, male, and Java origin. 
Doni Triono \& Akmad Solikin

Valuation Of Market Rental Value of a Planned Dormitory Using Hedonic Pricing Method: A Case Study of

Polytechnique of State Finance STAN, Indonesia

Meanwhile, the lowest simulation value is IDR11,719,521 (RM3,424.82), with the bathroom located outside the room, average remittances per month IDR1,000,000, earnings per month of IDR250,000, room size of $9 \mathrm{~m}^{2}$, type of residence of rent a house, female, and of Java origin.

\section{REFERENCES}

Anselin, L. (1988). Spatial econometrics: Methods and models. In Department of Geography and Economics, University of California, Santa Barbara, USA. Springer, Dordrecht. https://doi.org/https://doi.org/10.1007/978-94-015-7799-1

Asmawi, M. Z., Mohit, M. A., Noor, N. M., Abdullah, A., \& Paiman, T. (2018). Factor analysis on hedonic pricing model on open space affecting the housing price in Melaka and Seremban. Planning Malaysia, 16(6), 119-130.

Berndt, E. R. (1990). The practice of econometrics: Classic and contemporary. Reading, Mass.; Don Mills, Ont.: Addison-Wesley Publishing Company.

Bolt, K., Ruta, G., \& Sarraf, M. (2005). Estimating the cost of environmental degradation. In Report of the World Bank Environment Department (pp. 38-50). World Bank Washington.

Cró, S., \& Martins, A. M. (2017). The importance of security for hostel price premiums: European empirical evidence. Tourism Management, 60, 159-165. https://doi.org/10.1016/j.tourman.2016.11.021

Draper, N. R., \& Smith, H. (1998). Applied Regression Analysis (3ed ed.). John Wiley \& Sons.

Dubin, R. A. (1992). Spatial autocorrelation and neighborhood quality. Regional Science and Urban Economics, 22(3), 433-452.

Hite, D., Chern, W., Hitzhusen, F., \& Randall, A. (2001). Property-value impacts of an environmental disamenity: The case of landfills. Journal of Real Estate Finance and Economics, 22(2-3), 185-203.

Kong, F., Yin, H., \& Nakagoshi, N. (2007). Using GIS and landscape metrics in the hedonic price modeling of the amenity value of urban green space: A case study in Jinan City, China. Landscape and Urban Planning, 79(3-4), 240-252.

Majid, M. R., Zaman, M., \& Halim, N. (2018). Gis-based regression analysis of the relationship between ecological footprint and economic development of selected countries. Planning Malaysia, 16(7), 221-232.

Mohit, M. A., \& Mustafa, M. M. (2010). Analysis of commute charateristics and residential location choice of IIUM Gombak Campus Employees of Malaysia. Planning Malaysia, 8(1), 25-43.

Palmquist, R. B. (1984). Estimating the demand of characteristics of housing. Review of Economics and Statistics, 64, 394-404.

Ready, R. C., Berger, M. C., \& Blomquist, G. C. (1997). Measuring amenity benefits from farmland: Hedonic pricing vs. contingent valuation. Growth and Change, 28(4), 438-459.

Santos, G. E. de O. (2016). Worldwide hedonic prices of subjective characteristics of hostels. Tourism Management, 52, 451-454. https://doi.org/10.1016/j.tourman.2015.07.001

Suhaimi, N. A., Maimun, N. H. A., \& Sa'at, N. F. (2021). Does rail transport impact 
house prices and rents? Planning Malaysia, 19(16), 141-149.

Tsai, W.-P., \& Pan, N.-H. (2014). The Application of the artificial neural network in student dormitory rent - with Taiwan Sugar Corporation Hsianghe Dormitory as an example. Journal of Statistics and Management Systems, 17(1), 23-46. https://doi.org/10.1080/09720510.2013.857915

Received: $12^{\text {th }}$ July 2021. Accepted: $23^{\text {rd }}$ Sept 2021 